\title{
Banking union: the problem of untried systems
}

\author{
David G. Mayes \\ Department of Accounting and Finance, University of Auckland, Auckland, New Zealand; ARENA, \\ University of Oslo, Oslo, Norway
}

\begin{abstract}
This article explores the problems the EU and the SRB face in trying to implement a credible system for resolving banks without the use of taxpayer funds as a key part of banking union that avoids the doom loop between indebted banks and indebted sovereigns. It finds that without clear examples of how the system works in practice it is very difficult to provide convincing evidence of what will happen given the large number of options for bailing in, the continuing predilection for bailing out in some states and the lack of fiscal backstop for general threats to financial stability.
\end{abstract}

\section{Keywords}

Banking union; bail in; bail out; single resolution board; too big to fail

Banking union and the creation of the Single Resolution Board (SRB) in particular is a bold attempt to get away from problems of the past, where there seemed no practical alternative to bailing out large failing banks without causing a serious financial crisis - a problem made much worse where a country was so indebted that it could not afford the bail out. Unfortunately, the principal route to avoiding such bailouts is a tool that is largely untried on a large scale, namely the imposition of the losses on the creditors through bailing in. Furthermore, the SRB is itself a new organisation, without a track record and no obvious ability to borrow one from any of the constituent national resolution authorities, as the ECB did from the Bundesbank, as in the main they do not have suitable histories either.

For the SRB's procedures to work well they have to be implemented swiftly in the required form by the national authorities. Co-operation in this form has not been achieved before hence there will always be doubt about how it will work in future. Much of the success of a bail in regime comes from its being thought credible by the banks and their stakeholders. A credible threat that should something go wrong, the shareholders will be wiped out and the senior management will lose their jobs will help reduce the moral hazard generated by the previous expectation that they were "too big to fail". Bailing in is an expensive route to resolution and much of the gain from its existence stems from the incentive it gives to banks to find cheaper and more congenial private sector solutions through capital injections, mergers and acquisitions earlier in the process of decline. ${ }^{1}$

Initial experience has given a mixed message. In the case of Italy, the government has been unwilling to bail in junior bondholders in Banca Monte dei Paschi di Siena SpA (BMPS), Banca Populare di Vicenza and Veneto Banca, which became seriously undercapitalised. Raising the necessary capital on the market failed (Salzano and Speciale 2016). The government's reasoning is understandable as these bonds were viewed by the holders as being a substitute for term deposits. Bailing in is expected to impose losses on sophisticated richer investors and other institutions that are expected to be capable of assessing the risks they were taking and of bearing the losses without a major consequence for 
consumption and their standard of living. Even so this calls the likely success in avoiding bailing out in future into question (Wihlborg 2017).

However, the BMPS case has revealed a second problem, that of delay. Because the action proposed by the Italian Government required approval by the Commission to make sure that it did not violate state aid rules, the process was drawn out. Delay in bank resolution is a mistake. A bank can go from a soluble problem to a disastrous insolvency in a matter of hours. Having a process that takes days let alone months is not workable, as the case of Northern Rock in August/September 2007 vividly illustrates. If the Bank of England had reacted immediately in August 2007 and provided collateralised loans on the occasion of the first request, this would have given confidence to the market and Northern Rock might have been able to sort out its own problems without recourse to any state aid (Mayes and Wood 2008). As it was, nationalisation was required and the taxpayer ended up making losses. But even the process of resolution, once it was agreed, was marred because the announcement of the decision was delayed for a few days and, in the interim, there was a serious bank run from which Northern Rock could not recover. It appears that this lesson has not been learned. There is a danger that in rushing to handle the immediate problems of the combination of weak banks and heavily indebted states that the EU has not addressed the longer term financial stability issues of avoiding and managing future financial crises as effectively as it might (Elliott 2012).

The second case, the treatment of Banco Popular in Spain in June 2017, has, however, been much more promising (SRB 2017). The Spanish authorities stepped in as the share price plummeted to zero and the ECB determined that the bank was no longer viable, wiping out the shareholders and CoCoholders ${ }^{2}$ and converting a further tranche of junior bonds into equity. The bank was then sold for one euro to Banco Santander, which will inject the necessary new capital. ${ }^{3}$ Of course the implications for future such resolutions will not be clear until the courts have adjudicated on the various legal claims that have been lodged against the authorities by the losers.

The difference between the two treatments in part no doubt reflects the different attitudes of the Italian and Spanish authorities, which implies some lack of power for the SRB, but there were differences in the nature of the bondholders, which had implications for the potential contagion and impact on public confidence in the banking system in the two countries.

This article therefore focuses on two issues

(1) Whether the SRB will be able to function sufficiently efficiently. (Huertas (2016) has argued, for example, that the timetable laid down for decision-making is implausible.)

(2) Whether bailing in can actually provide a plausible substitute for bailing out.

\section{Making sure the SRB can work}

Smooth and timely cross-border resolution faces a number of fundamental problems: lack of information sharing among different authorities; lack of consistency in the tools available and the circumstances in which intervention can take place ${ }^{4}$; the need to use the national authorities to undertake judicial proceedings in each jurisdiction; opaque structures in the subject banks; conflicts of interest across the different countries and hence the difficulty of getting agreement. The FSB has made extensive recommendations as to how these problems might be overcome (FSB 2014, 2015). But the underlying conclusion is that one of two structures will work. The first is where the home country resolves the whole problem itself without needing more than the acquiescence of the host country authorities. ${ }^{5}$ This is labelled Single Point of Entry. The alternative is that the banking group is 
structured so that each country can make its own decisions in resolution without having to pay too much regard to the actions of the others - multiple point of entry. The middle ground of relying on co-operation was regarded as being too difficult in circumstances where rapid and decisive action is required (Krimminger 2016). But this of course is where the EU predilection lies.

The main issue for resolving a bank which is important in a jurisdiction is that it cannot be allowed to stop operating there or this will result in major losses and probably a more general crisis of confidence in the local financial system. Prior to the global financial crisis this was labelled "too big to fail" and the expectation was that the state would have to intervene and bail the bank out with taxpayers' money, as there was no obvious alternative available within the existing law. This is precisely what happened in most cases in the EU in the crisis. Howarth and Quaglia $(2016,115)$ suggest that "A resolution regime is ultimately a political solution to underlying distributive conflicts surrounding bank failure". What the BRRD/SRR has done is on the one hand agree a set of rules for that distribution and on the other try to make the circumstances such that in any particular case the outcome can be more a technical solution given the rules than an exercise in political horse trading at the time.

With the BRRD (Bank Recovery and Resolution Directive), the SRB and the SRF (Single Resolution Fund), the problem should be much smaller than in the past, as normally there will be no burden to share. The holders of what is called "loss absorbing capacity" will cover the losses and if there are other costs for the resolution authorities these will be met from the respective resolution funds (up to $1 \%$ of the values of insured deposits) which will be the SRF for the SSM (Single Supervisory Mechanism) countries. ${ }^{6}$

In line with FSB (2014) recommendations, the SRB is now required to have in place agreed resolution plans for all of the banks under its direct responsibility (SRR art. 8) ${ }^{7}$ and the ECB has to have established a "recovery plan" for each of them as well (BRRD art. 5-9 and SSMR art 4(1)(i)). ${ }^{8}$ A recovery plan, which is the responsibility of the subject bank but has to be agreed by the authorities, explains how it will restructure to return to viability quickly and without recourse to public funds or other support. A resolution plan, which is produced by the SRB/resolution authorities themselves, sets out how they would resolve the bank should it reach the point of actual failure or the point where failure seems inevitable (SRR art. 18(1)). These are not public documents so we can only guess their plausibility. But there are good grounds for scepticism (Binder 2016), both because of the softness of the assumptions and the surprise nature of previous problems with banks. ${ }^{9}$

The position of the SRB is somewhat unusual. Indeed (SRR (31)) reads: "In order to ensure a swift and effective decision-making process in resolution, the Board should be a specific Union agency with a specific structure, corresponding to its specific tasks, and which departs from the model of all other agencies of the Union". It was created by the SRR and is based in Brussels. While it has a technical job to do it is operating in an area where there is strong political concern, namely crisis management. In a single state it would be normal for crisis management to involve four groups: the central bank, the ministry of finance, the supervisory agency and the resolution agency. ${ }^{10}$ In a crisis, the heads of all four would meet regularly and the minister of finance would have a pre-eminent role - probably chairing the group. In a crisis, parliaments are normally informed but rarely consulted as decisions have to be taken quickly and need to be irrevocable in order to manage market volatility - uncertainty increases costs and may well stop markets working altogether, as was seen in the global financial crisis. Occasionally, the government needs new powers and if, as in the case of TARP in the US, the request is not immediately granted this can simply add to the problem. Normally, accountability is exercised after the crisis and not at the time. 
No matching involvement of the main agencies of this form is built into the SRR but clearly the ECB and the SRB will work closely together (SRR art 30) as it is the ECB that provides the main information and is the institution that would normally decide if a bank is no longer viable and hence that the SRB ought to intervene (SRR art 18). In the SRB case the Commission, can intervene in the decision-making process after the SRB has made its proposal. The grounds on which it can intervene are limited and relate to what is described as "the discretionary aspects of the resolution scheme", which appears to be in terms of whether the resolution is "necessary in the public interest" and to any "material modification" of the amount from the SRF included in the proposal (SRR art 18). If the Commission does take the opportunity to intervene then this opens up the decision to intervention by the Council. Thus, at this stage a political view could be introduced into the official decision-making. (The Commission can also intervene if it feels that the planned actions are incompatible with state aid policies (SRR art 19) and the SRB can refer the case to the Commission if it thinks that governments' interventions constitute state aid.) $)^{11}$

It seems rather unlikely that strong political views would not be held about what should be done in the event of the failure of a large bank that has systemic importance in one or more countries. It is even more unlikely that these views would not be aired if they disagreed with the SRB. In these circumstances a member state might intervene. While there are processes to challenge such intervention, in the fast moving circumstances of a crisis, the intervention is likely to be effective.

Speed is essential in resolution in several respects. If a resolution of a large institution is to be successful then it has to take place without the business of the bank stopping, otherwise it would default and contracts would be closed out. This means that the whole process must be completed between the closing of business on one day and the opening of it on the next. Thus, one might have 12-14 hours overnight or nearer 60 hours if the resolution is performed over a weekend. ${ }^{12}$ The position is complicated by the fact that overseas markets will still be open. To be able to perform a resolution that quickly the resolution authority has to be very well prepared.

To an extent this can be done through resolution plans, whereby the SRB works out how each of the major institutions might be resolved under a variety of scenarios in the time available. But it also requires careful structuring of the banking group so that it can be handled effectively across the various jurisdictions. Thus, the SRB can insist on (SRR art 10). Normally, implementing a plan successfully requires a considerable period of preparation, as it is necessary to find buyers and work out which forms of reorganisation are feasible in the circumstances.

In the SRB's case it is not clear that resolutions can get through the decision-making process fast enough to be practicable (Huertas 2016). First of all, the SRB has to decide what to do, which itself could take a few hours if the failure is a surprise or comes a lot earlier than expected. It then has to communicate this decision to the Commission which has 24 hours to respond. If the Commission endorses the scheme then it can be put into immediate effect. If it does not, the Commission can propose to the Council that the scheme should be amended within 12 hours of its submission. If the Council agrees with the Commission then the Board has 8 hours to alter its resolution scheme to fit with the Commission's requirements. If the resolution scheme is not agreed then the bank in question will simply be wound up following national law.

If this complicated procedure is followed through, half of the time for effecting the resolution would already have been used up and the idea of managing a resolution overnight would be impossible. Clearly, the whole process is predicated on the idea that there will be sufficient lead time that the ideas will already have been agreed unofficially so that the official process then becomes a formality that can be executed very quickly. But that in turn assumes that there are no strong objections. It also 
creates a major opportunity for leaks. If rumours of a decision get out then markets will react and, as the case of Northern Rock illustrates, can make the position much worse. If the decisions of the SRB are open to question then it may be difficult to get possible purchasers to show interest as they will need to attempt due diligence before agreeing which is a costly process.

Secondly, the main weapons in the SRB's arsenal are largely untried. The first line of defence when a bank gets into trouble is that it should try to turn itself round, without breaching the regulatory limits. All large banks are required to have plans in place to achieve this, labelled "recovery plans". There is considerable scepticism over whether these will work for a number of reasons. The authorities did not find the initial plans plausible (Carmassi and Herring 2014; FDIC 2014). They rest on assumptions, particularly about access to funds and financial markets and being able to dispose of assets to raise capital/cash. As the global financial crisis has shown, these can dry up. The principal weapon that should work in these circumstances is bailing in but this also is untried in the context of a recovery. Banks have issued contingent convertible securities (CoCos) whose conversion can be triggered if the bank's capital falls too close to the regulatory limit. At that point the security, which is an enhanced junior bond, can either be written down or converted into equity. In either event this has a positive impact on the bank's balance sheet. In the event of a write down then the bank's debt is simply reduced, thus enabling it to absorb at least some of the losses. In the event of a conversion of the bond into equity then capital is increased and the bank no longer has an obligation to pay back the bondholder.

There are other worries about CoCos, the principal one being that their triggering might precipitate a more general loss of confidence in the banking system (Goodhart 2010). This makes bank recoveries a lot less likely and more importantly it gives banks some confidence that, whatever the BRRD might say, they will in fact be bailed out. This will constitute a moral hazard but it will also have the ironic impact of reducing the cost of large banks' capital, as lenders will also assume that the chance of their making losses is reduced. Tröger (2017) argues that because there is so much discretion in the BRRD about how bailing in can be organised, it is simply too complex to use for a cross-border bank.

If bailing in is not used then the SRB will have to resort to some of the BRRD's other main tools, although it may well have been sensible to use those tools in combination with the bail in anyway. This restructuring might involve separating out impaired loans and placing them in a "bad bank"/asset management company or dividing up the bank and selling parts. For example, the SRB might decide to sell off non-banking parts of the group in order to provide a greater capital cushion for the banking business. Once the SRB gets involved in detailed characteristics of a resolution, the process is likely to become highly political. Ideally, a resolution is a technical issue with the resolution authority being able to follow whichever course of action it feels will be best aligned with its terms of reference. Any such action involving an important bank would of course be subject to review after the event. But, at the time, the resolution authority's actions must be final and not capable of challenge even though recompense will be in order where the authority has acted incorrectly. Thus, for example, the new owners of a bank cannot suddenly find that they no longer have control of the bank if well after the event it becomes clear that operation had positive value at the time of intervention and the shareholders should not have been written down to zero. The writing down needs to stand but the former shareholders need to be compensated up to the hypothesised value that their shares should have had at the point when the writing down took place (SRR, art 20). ${ }^{13}$

The SRB has a further problem as it has to act through the relevant authorities in each of the jurisdictions who are recognised by the local courts. If a government is unhappy with the SRB's decision, this would put the national resolution agency in a difficult position. ${ }^{14}$ In a resolution, action 
has to be swift. There is little time to argue and certainly any argument in public is likely to result in a loss of confidence.

One of the problems for the SRB is that it is not fully in charge of its own destiny. Problems up to the point of failure are the responsibility of the supervisory authorities, ${ }^{15}$ i.e. for the large banks, the ECB. Through the phases of concern and recovery, the ECB is in charge of the process. It is only when the bank is insolvent or the ECB considers that it is bound to become insolvent that the SRB steps in. With an integrated system, as in the UK, the various phases can be more readily handled as a coherent process and the merits of taking risky steps to help a recovery that are likely to make the losses in resolution worse if they fail can be debated more readily. As it is, the SRB has to live with any decisions the ECB makes; see Singh (2016) for a comprehensive discussion. The EBA has been formulating guidelines on how to reconcile the requirements of competent and resolution authorities (for example, EBA 2015).

That said, there are clear advantages of having a resolution agency that is separate from the supervisory institution (Elliott 2012; Masciandaro and Quintyn 2015). The most obvious is that their incentives are different. For a supervisor, any bank failure is bound to have at least a tinge of supervisory failure attached to it. It will always be possible to argue that if only they had been more observant or acted earlier or more forcefully the failure could have been avoided. Indeed, as the Material Loss Reviews after the global financial crisis indicated, in most cases the US supervisors missed the "red flags" (Garcia 2012). Hence, a supervisor has a strong incentive to find a way out of the problem short of failure. And, indeed, that is the right incentive, because resolutions tend to be more costly than if some earlier private sector solution can be found. On the other hand, if, like the FDIC, the objective of the resolution agency is to minimise its losses, then it has an incentive to try to start its activities as soon as possible before losses mount. The best solution is likely to come from a constructive pressure between the two forces. Again in the US, the avoidance of delay is built in. If a bank is critically undercapitalised it has to return to adequate capitalisation within 90 days or it will be compulsorily resolved. The FDIC begins its task as soon as the regulatory limits are approached, it does not wait until failure is inevitable. ${ }^{16}$

The SRB is in a more difficult position, but while it has five objectives (SRR art 15(2)), it is instructed that "When pursuing the objectives ... the Board, the Council, the Commission and, where relevant, the national resolution authorities, shall seek to minimise the cost of resolution and avoid destruction of value unless necessary to achieve the resolution objectives" ${ }^{17}$ However, the "objectives are of equal significance, and shall be balanced, as appropriate, to the nature and circumstances of each case" (SRR art 14(3)). Hence, what will be done in any specific case is not clear unless the SRB chooses to spell out the principles in advance. While SRR $\$ 2$ and art 13 are labelled "Early intervention" there is no matching set of "prompt corrective action" requirements to those in the US. Responsibility for any such actions lies with the supervisors (competent authorities).

One clear prior requirement the SRB places on the "competent" authorities is that they must ensure that the banks are all "resolvable", in the sense that they have a structure that would permit the SRB to perform a satisfactory resolution with adequate speed and limited cost. There has always been the fear that large banks are "too complex to resolve" (Herring 2005; Carmassi and Herring 2013) and hence remain "too big to fail".

The first stage of the process of correcting a bank's problems will be undertaken by the management while trying not to give any signs of difficulty. Their internal information will indicate the problems. At a later stage the problems will also become clear to the supervisors who will urge action before regulatory limits are reached. Some of this action will be automatic, with the triggering of CoCos, 
which will take effect as part of "recovery" processes that are intended to turn the bank round without failure. The SRB will be a party to these plans but much of the responsibility for overseeing their execution will lie with the ECB and the other "competent authorities".

\section{Avoiding bailing out}

One aspect of banking union continues to cause controversy. This whether the BRRD/ SRR and the creation of the SRB has in fact meant that it is unlikely that the taxpayer will be called on to bail out banks in the future. The fact that the taxpayer has been called on already in the case BMPS and the wider problems in the Italian banking system suggests that the answer may be no. One reason in favour of bailing out, however, is the potential reaction of those who hold bonds in other banks. Since other Italian banks are holding substantial impaired loans on their books (Veron 2016) bondholders in those banks might well feel that could also be bailed in. This may therefore cause them to try to sell the bonds, thereby driving down prices and causing instability which would also spill over into the share market, making the capital position of the banks even worse. This fear may or may not be borne out in practice but it is legitimate for a government to decide that it does not want to run the risk of finding out.

Similar circumstances are likely to apply in the case of serious problems with any large bank. The authorities will always be apprehensive that ordinary investors may fear that they will be next in line to bear losses and hence will try to exit, thereby causing just the problem they seek to avoid. ${ }^{18}$ This means that although the bail in tool (and the other resolution tools) can be applied by the SRB and other resolution authorities successfully in a technical sense - the bank can be returned to proper capitalisation and profitability - the fear of spillover consequences may be such that the measures are not employed or at least that they have to be backed up by state intervention, say in the form of issuing a blanket guarantee against further losses. ${ }^{19}$ Such guarantees proved necessary in the Nordic crises (Mayes 2016) and also in the global financial crisis when Anglo-Irish Bank and others needed to be bailed out. Even the existence of a bail out was thought insufficient to reassure investors in the rest of the system. Once one country felt it necessary to issue such guarantees, others felt obliged to make similar offers thus committing the taxpayer to considerable potential exposure.

The problem with the triggering of guarantees or other governmental processes is that these lie outside the competence of the SRB. These are crisis resolution measures rather than bank resolution measures. The same applies to macro-prudential measures and liquidity measures that are applied to the sector as a whole. Liquidity measures will be orchestrated by the ECB for the euro area although they may in the main be implemented by the national central banks. Outside the euro area, even if this relates to SSM countries, this will be the national central banks' responsibility. Clearly, the ESRB will have a role here although unlike the SRB it is not an executive agency and can only push the national authorities into action not compel them. This therefore risks a confusion between what the SRB is trying to achieve with individual institutions and what the national authorities are trying to achieve for the system as a whole.

In the case of BMPS the capital injection by the Italian Government was "preventative" to avoid wider systemic concerns and hence permissible under the SRR. It hence occurred before the SRB gained responsibility for the bank and indeed it is likely to be sufficient for the BMPS to avoid failure. If this mechanism were used widely during the recovery phase then this would weaken the role of the SRB. ${ }^{20}$ One reason for thinking that governments may prefer to bail out rather than bail in is simply the nature of the short-run impact on the economy. If those bailed in can easily absorb the loss and there will be 
little knock on impact onto their consumption and investment expenditures, ${ }^{21}$ say because they are hedge funds, then bailing in will look attractive. However, if they are retail investors or other financial institutions who have difficulty absorbing the loss, then the position will appear very different. With a bail in losses are incurred immediately and indeed since values tend to be artificially low in a crisis, the initial loss may be more than the longer term loss. With a bail out, however, the losses are spread over future tax payments. Thus, for a bail out the loss is spread thinly over a large number of people and over a long time. With a bail in, the loss may be much more concentrated both over households and time. Immediate losses will be politically much more difficult to bear so there will be a strong incentive to bail out (Karamichailidou and Mayes 2016). ${ }^{22}$ As (IMF 2014, 12) puts it: "Holders of claims targeted for bail-in must be able to absorb potential losses without generating systemic risk themselves as a consequence of their financial losses".

\section{Concluding remarks}

As far as the SRB itself is concerned, it remains to be seen how well early intervention will go, given the division of responsibility between itself and the ECB and national supervisors (the "competent authorities"). There is a history of reluctance to be overcome, such as the resolutions of Banco Espirito Santo and Banco Internacional do Funchal in Portugal that Donnelly (2017) cites. However, the case of Banco Popular is more promising as this followed a textbook swift timetable. If the enhanced capital buffers and the extent of the resources that can be bailed in work as planned then the need for resolutions should in any case fall. But the bail in tool, whether triggered during the recovery phase or imposed in a resolution, is untried in large institutions and has previously experienced difficulty in small ones (Poulsen and Andreasen 2011). One fear is that the triggering of CoCos will simply bring forward the onset of a more general crisis through a general loss of confidence in the system. Nevertheless, the immediate lack of reaction to the bail in of Banco Popular is encouraging in this regard.

Similarly, it is not clear how well in practice the SRB will be able to act in a crisis. Success depends first of all on the planning and early preparations once it becomes clear that the bank is likely to be in trouble. The success of the implementation relies on the decision-making being swift and not disturbed by political concerns. If the Commission and the Council use their powers of rejection, a resolution could become very messy. Implementation involving various national authorities in a range of member states acting in close coordination is also largely untried. The precedents in the global financial crisis, especially with Fortis (Gros and Schoenmaker 2014; IMF 2014), are not particularly encouraging. How governments will react to the extreme risks and uncertainties in a crisis is difficult to forecast. Under pressure, plans are often ignored and mistakes are made. The cases of Banco Popular and BMPS illustrate different ends of the spectrum, showing promptness in the first case and forbearance in the second. The fact that the Italian authorities can come up with a plausible case for avoiding a bail in illustrates the inherent uncertainty in such processes. Donnelly (2017) argues that there is considerable scope for national authorities to resist bail ins.

One of the key reasons for introducing the BRRD/SRR in the first place was to try to break the vicious circle between troubled banks and heavily indebted member states. By a combination of using resolution methods that did not require public funds and calling on the SRF then pressure on the sovereign would be reduced - not eliminated because a serious banking problem is likely to be accompanied by a slowing of the economy and an increase in the state's need to borrow. If, however, member states feel the need to intervene earlier in preventative mode, then this will trigger the need 
to call on the ESM earlier. The example of the intervention by Italy in their present banking problems, especially with BMPS, illustrates the point all too clearly.

\section{Notes}

1. See RBNZ (2012) for an assessment of the costs of the different forms of resolution.

2. Contingent convertible bonds that can be written down or converted into equity if the bank's capital or viability passes below a prescribed trigger value.

3. Clearly, the authorities were well prepared and the SRB and the Spanish resolution authority FROB (Fondo de Reestructuración Ordenada Bancaria) would have sorted out the way forward with Santander before the resolution was triggered.

4. Particularly in the ability to act early while the shareholders are still running the company.

5. In other words that they do not frustrate the process say by refusing to allow a subsidiary to be sold.

6. It is worth noting that the SRF is not simply a source of funds that can be used by the SRB in a resolution as some sort of tax on the banking industry. SRR Art 76(3) makes it clear that "The Fund shall not be used directly to absorb the losses of an entity ... or to recapitalise such an entity". While the fund cannot be used until a bail in of at least $8 \%$ of total liabilities has been made, it can only be used for six specific purposes thereafter (SRR art 76(1)) which include guarantees, loans, purchasing assets, contributing to a bridge bank/asset management vehicle, paying compensation to creditors/shareholders and making contributions in lieu if a creditor group has been excluded from the bail in. An expectation that the SRF would be used up to its full capacity, if needed, as soon as the $8 \%$ bail in was achieved would help explain some of the opposition to the fund and its mutualisation.

7. Single Resolution Regulation (SRR) - Regulation (EU) No 806/2014 of the European Parliament and of the Council of 15 July 2014 establishing uniform rules and a uniform procedure for the resolution of credit institutions and certain investment firms in the framework of a Single Resolution Mechanism and a Single Resolution Fund and amending Regulation (EU) No 1093/2010.

8. In each case this is to be agreed in collaboration with the relevant national authorities.

9. Singh (2016) explains the convoluted relationship between the two types of plan and the authorities involved. FDIC (2014) illustrates the difficulty in providing plausible plans.

10. If there were a separate macro-prudential agency then this would be included as well and of course if some of the other functions are performed by the same agency then the number of participants would be reduced.

11. In such a case, the Commission would undertake an "in-depth investigation" (SRR art 19 (3)) which could delay the process considerably, as is illustrated by the delays in agreeing the support package for BMPS.

12. Usually, the authorities can manage to allow a troubled bank to limp along so that it fails on a Friday evening.

13. It is very difficult to get accurate valuations in a crisis. Many institutions will find they need more liquidity and will hence sell rather illiquid assets at low prices, thereby depressing the market price, 
and any attempt to raise new capital will be expensive in such an uncertain world. Thus, not only are current prices poor indicators of underlying values in those circumstances but the actions of each institution in trying to solve its own problems makes the prices more unfavourable for all the others in a downward spiral of difficulty (de Grauwe, 2013). All this makes it more attractive for a government bailout as then the government will be able to buy bank assets cheaply and hope to sell them at a profit later, as in the Swedish financial crisis in the early 1990s (Mayes 2016). As Poulsen and Andreasen (2011) record, in the case of Amagerbanken, the main bail in attempted thus far, the initial valuation of the assets and losses was too pessimistic and a smaller bail in was eventually agreed.

14. A governmental wish to do something other than apply the BRRD directly is readily possible as the BMPS example illustrates.

15. These are called the "competent" authorities in the wording of the BRRD, to distinguish them from the resolution authorities.

16. Thus, the FDIC starts when a bank changes from being "well capitalised", which entails having a $2 \%$ margin over the minimum required capital adequacy ratio, to being "adequately capitalised", which means that is merely above the minimum requirement. (https://www.fdic.gov/regulations/safety/manual/section2-1.pdf, at 2.18-9.).

17. The objectives are: "(a) to ensure the continuity of critical functions; (b) to avoid adverse effects on financial stability ... ; (c) to protect public funds by minimising reliance on extraordinary public financial support; (d) to protect depositors [covered by the relevant Directives]; (e) to protect client funds and client assets" (SRR art 14(2).

18. Elliott (2012) points out that this contagion not only applies to holders of similar bailinable debt in other banks but also to the holders of more senior instruments in the same bank as they may fear that the losses will be so great that they will also be called upon to share in the loss.

19. A related worry is that the SRF will run out of money. Although studies of the likely demands on the SRF from failures in a major bank suggest it will have sufficient cover (Schoenmaker 2010; Hüser et al. 2017), they are single bank studies and do not allow for the contagion that may mean that other banks may need to draw on the fund as a whole. While Hüser et al. (2017) allow for direct contagion, in the sense that losses to counterparties lead them to fail as well, they do not consider the indirect contagion caused by a fall in confidence in the market as a whole. The fact that TARP was $\$ 700 \mathrm{bn}$, while the SRF will be $€ 55 \mathrm{bn}$ suggests that major funding may still be needed from governments. However, the impact on the SRF alone might be affordable under the SRR rules (Huertas and Nieto 2014) with the balance falling elsewhere. Schoenmaker (2010) estimates a possible financing cost for the failure of HSBC of $€ 100 \mathrm{bn}$ but then most of the cost falls on the UK not the SRF.

20. Gros (2013) suggests that past experience indicates that actually Germany is the most likely country to invoke systemic stability as a means for intervening early with public money as there is no example in recent years of where any creditor however junior has been allowed to make any losses in the event of bank failure in Germany.

21. Which is the expectation in the case of Banco Popular (SRB 2017).

22. Hüser et al. (2017) explore the possible knock on effect of simulated bailing in for the 26 largest banks in the euro area on financial sector creditors. They find that there are no knock on failures but they do not consider the problems of falling asset prices and a general loss of confidence. 


\section{References}

Binder, J.-H. 2016. "Resolution Planning and Structural Bank Reform within the Banking Union." In European Banking Union: Prospects and Challenges, edited by J. E. Castañeda, D. G. Mayes, and G. E. Wood, 129-155. Abingdon: Routledge.

Carmassi, J., and R. Herring. 2013. "Living Wills and Cross-border Resolution of Systemically Important Banks." Journal of Financial Economic Policy 5 (4): 361-387.

Carmassi, J., and R. Herring. 2014. "Corporate Structures, Transparency and Resolvability of Globally Systemically Important Banks." Accessed 24 April 2015. https://www.systemicriskcouncil.org/wpcontent/uploads/2015/01/Carmassi-Herring Corporate-Structures-Transparency-and-Resolvabilityof-G-SIBs.pdf.

Donnelly, S. 2017. "Liberal Economic Nationalism, Financial Stability and Commission Leniency in Banking Union." Paper Presented at the Workshop on 'Reforming Banking Union', University of Luxembourg, Luxembourg, June 12.

EBA. 2015. Final Report on Draft Regulatory Technical Standards and Guidelines on Business Reorganisation Plans, EBA/RTS/2015/12 and EBA/GL/2015/21. European Banking Authority. Accessed February 3, 2017. https://eba.europa.eu/documents/10180/1312804/EBA-RTS-2015-12+RTS+and+ EBA-GL-2015-21+GLs+on+Business+Reorganisation+Plans.pdf.

Elliott, D. 2012. "Key Issues on European Banking Union: Trade-offs and Some Recommendations." Global Economy and Development Working Paper 52, Brookings.

FDIC. 2014. "Statement by Vice Chairman Thomas M. Hoenig, 'Credibility of the 2013 Living Wills Submitted by First Wave Filers'." Accessed October 30, 2014. Https://www.fdic.gov/ news/news/speeches/spaug0514a.pdf

FSB (Financial Stability Board). 2014. "Key Attributes of Effective Resolution Regimes." Accessed January 30, 2017. http://www.fsb.org/wp-content/uploads/r 141015.pdf

FSB (Financial Stability Board). 2015. "Principles for Cross-border Effectiveness of Resolution Actions." Accessed January 30, 2017. http://www.fsb.org/wp-content/uploads/Principles-forCross-borderEffectiveness-of-Resolution-Actions.pdf

Garcia, G. G. 2012. "Missing the Red Flags." In Reforming the Governance of the Financial Sector, edited by D. G. Mayes and G. E. Wood, 220-237. Abingdon: Routledge.

Goodhart, C. 2010. "Are Cocos from Cloud Cuckoo Land?." VOXeu. Accessed February 3, 2017. http://voxeu.org/article/are-cocos-cloud-cuckoo-land

de Grauwe, P. 2013. "Design Failures in the Euro Zone: Can they be Fixed?." European Economy Economic Working Paper 491, European Commission. Accessed 5 February 2017. http://ec.europa.eu/ economy finance/publications/economic paper/2013/pdf/ecp491 en.pdf

Gros, D. 2013. "The SRM and the Dream to Resolve Banks Without Public Money." CEPS Commentary. Accessed February 5, 2017. https://www.ceps.eu/system/files/DG\%20SRM\%20and\%20the\%20dream \%20to\%20resolve\%20banks\%20without\%20public\%20money.pdf.

Gros, D., and D. Schoenmaker. 2014. "European Deposit Insurance and Resolution in the Banking Union." Journal of Common Market Studies 52 (3): 529-546. 
Herring, R. 2005. "Too Complex to Fail: International Financial Conglomerates and the Design of National Insolvency Regimes." Address to the 5th Annual Seminar on Policy Challenges for the International Financial System; International Financial Conglomerates: Issues and Challenges, Washington, DC.

Howarth, D., and L. Quaglia. 2016. The Political Economy of Banking Union. Oxford: Oxford University Press.

Huertas, T. F. 2016. "Banking Union the Way Forward." In European Banking Union: Prospects and Challenges, edited by J. E. Castañeda, D. G. Mayes, and G. E. Wood, 23-37. Abingdon: Routledge.

Huertas, T. F., and M. J. Nieto. 2014. "How Much is Enough? The Case of the Resolution Fund in Europe." Accessed February 7, 2017. https://voxeu.org/article/ensuring-european-resolution-fundlarge-enough.

Hüser, A.-C., G. Halaj, C. Kok, C. Perales, and A. van der Kraaij. 2017. "The Systemic Implications of BailIn: A Multi-Layered Network Approach." ECB Working Paper no. 2010, Frankfurt.

IMF. 2014. "Cross-Border Bank Resolution: Recent Developments." Accessed February 4, 2017. http://www.imf.org/external/np/pp/eng/2014/060214.pdf

Karamichailidou, G., and D. G. Mayes. 2016. "Plausible Recovery and Resolution Plans for Cross-Border Financial Institutions." In European Banking Union: Prospects and Challenges, edited by J. E. Castañeda, D. G. Mayes, and G. E. Wood, 38-66. Abingdon: Routledge.

Krimminger, M. 2016. "Shadows and Mirrors: The Role of Debt in the Developing Resolution Strategies in the US, UK and European Union." In European Banking Union: Prospects and Challenges, edited by J. E. Castañeda, D. G. Mayes, and G. E. Wood, 156-183. Abingdon: Routledge.

Masciandaro, D., and M. Quintyn. 2015. "The Governance of Financial Supervision: Recent Developments." Journal of Economic Surveys 30 (5): 982-1006.

Mayes, D. G. 2016. "Top Down Restructuring of Markets and Institutions: The Nordic Banking Crises." Journal of Banking Regulation 18 (3): 213-232. doi:10.1057/s41261-016-0006-z.

Mayes, D. G., and G. E. Wood. 2008. "Lessons from the Northern Rock Episode." Économie Internationale 114: 5-27.

Poulsen, U. L., and B. L. Andreasen. 2011. "Handling Distressed Banks in Denmark." In Nationalbankens Kvartalsoversigt, 3, 81-96. Copenhagen: Danmarks Nationalbank.

RBNZ. 2012. "Regulatory Impact Assessment of Pre-Positioning for Open Bank Resolution." Reserve Bank of New Zealand. Accessed February 3, 2017. https://www.rbnz.govt.nz/-/media/ReserveBank/ Files/regulation-and-supervision/banks/policy/5014272.pdf?la=en.

Salzano, G., and A. Speciale. 2016. "Bank Bondholders Italy Aims to Protect are not all that Poor. Accessed December 29, 2016. https://www.bloomberg.com/news/articles/2016-12-22/italian-bankbondholders-gentiloni-aims-to-shield-aren-t-so-poor.

Schoenmaker, D. 2010. "Burden Sharing." Estabilidad Financiera 18: 32-47. Banco de España.

Singh, D. 2016. "Recovery and Resolution Planning: Reconfiguring Financial Regulation and Supervision." In Bank Resolution: the European Regime, edited by J.-H. Binder and D. Singh, 1-24. Oxford: Oxford University Press. 
SRB. 2017. "The Single Resolution Board adopts resolution decision for Banco Popular." Accessed June 26, 2017. https://srb.europa.eu/en/node/315

Tröger, T. H. 2017. "Too Complex to Work: A Critical Assessment of the Bail-in Tool Under the European bank Recovery and Resolution Regime." SAFE Working Paper no. 178, Frankfurt.

Veron, N. 2016. "Italy's Banking Problem is Serious but can be Fixed." Bruegel Institute. Accessed February 3, 2017. http://bruegel.org/2016/07/italys-banking-problem-is-serious-but-can-be-fixed/.

Wihlborg, C. 2017. "Bail-ins: Issues of Credibility and Contagion." SUERF Policy Note. Accessed February 7, 2017. www.suerf.org/policynotes. 